\title{
Management of Transportation Land (Study on Becak Motor Transportation in Tempe District of Wajo Regency)
}

\author{
$1^{\text {st }}$ Fakhri Kahar \\ Departemen of Public Adminsitration \\ Public Administration Department \\ Universitas Negeri Makassar \\ Makassar, Indonesia \\ fakhri.kahar@unm.ac.id
}

\author{
$2^{\text {nd }}$ Aslinda \\ Departemen of Public Adminsitration \\ faculty of sosial science \\ Universitas Negeri Makassar \\ Makassar, Indonesia \\ aslinda@unm.ac.id
}

\begin{abstract}
The purpose of this study is to know the Public Perception of the management of Transportation Becak motor (Bemo) in Tempe District of Wajo Regency. This research will be conducted in Wajo District, Tempe Sub-district which is one of the districts that have increased the use of a motorcycle in Sulawesi. The research stage is to observe the field to get an idea about the utilization of Bemo to support the activities of the community, to distribute the questionnaires to the users of Bemo to find out the public perception on the management of Bemo, and the questionnaire to the owner of the motor rickshaw to know the income level. The result of research indicates that society generally agrees that Bemo transportation service in District of Tempe Wajo Regency pays attention to transportation management system which includes: planning, organizing, controlling, and evaluation phase.
\end{abstract}

Keywords- Management, Transportation, Becak motor (Bemo)

\section{INTRODUCTION}

Mode of transportation has a very vital and strategic role in various aspects of life in society, nation and state [1]. The importance of land, sea, and air transportation modes, is illustrated by the increasing demand for transportation services to support the mobility of people from one region to another to meet their daily needs. Good transportation will play an important role in the development of a region, especially in accessibility, while accessibility is defined as the ease and capability of an area or space to be accessed or reached by outside parties of the area either directly or indirectly [2]-[5]. Easily a location is linked to other locations through existing transportation networks, in the form of road infrastructure and transport equipment moving on it. Rural development is slowing and hampered by the lack of available means of transportation [6].

Wajo regency is one of the regencies in South Sulawesi with high economic activity. It is proven that Wajo Regency can contribute $5.1 \%$ to the economic growth of South Sulawesi. Based on data from Bank Indonesia Representative Office (KPBI) Makassar 2014, the three major contributors to economic growth in South Sulawesi, namely Makassar with a contribution of $33.1 \%$, followed by Bone District by $6.8 \%$, then East Luwu with a contribution of $6.7 \%$ and fourth place is occupied by Wajo Regency with a contribution of $5.1 \%$. Then Pangkep and Pinrang districts each contributed $5.0 \%$ and $4.7 \%$ respectively.

While other regencies/cities have contributed to the economic growth of South Sulawesi is still below 2\%. In carrying out economic activity is highly dependent on various modes of transportation (private vehicles or public transport passengers), which the community uses in carrying out daily activities. In fact, in several cities on the island of Sulawesi and Sumatra, (Makassar, Pangkep, Sidrap, Wajo, Gorontalo, Manado, Aceh, Medan, Sipirok and so on), people are innovating to find solutions using alternative modes of informal transportation in the form of motorcycles, and the last one developed very rapidly is a Bemo a combination of Motor Duck and Traditional Becak).

Bemo has grown quite rapidly since 2003 and has become one of the most popular alternative transport vehicles. Becak Motor (Bemo) has the ability to reach all areas of the city / rural, travel time and operation, as well as affordable costs by the public and door to door services, making the competitiveness high enough, to compete with public transportation, oplet / Pete-Pete, traditional and motorcycle motorcycles in the transportation service to the public. As in Wajo District, Bemo grew and developed between February and March 2003 with considerable speed and became one of the alternative transportation platforms [7]. In addition to the ability of motor becak in reaching all areas of Sengkang City, as well as travel time to get to the destination quickly make the bemor have high competitiveness in providing transportation services to the public. Moreover, the road network in Sengkang City that form the grid pattern and narrow alley and hilly with an average height of 5-10 meters where not all the road network becomes the route of Pete-Pete and other public transport passengers. Only operate generally from 05.00 to 18.00 , bemor can operate until 22:00 hours or more. This is 
certainly the underlying community to use the mode of bemo with the assumption of time efficiency, and accessibility is high enough.

Good transportation services certainly can not be separated from the management that must be applied by the owner of modes of transportation including the case of Bemo, so that consumers feel comfortable and safe in using the transportation services. Therefore, bemor moves in providing transportation services hence the owners of the modes should pay attention to several factors: 1) Speed; 2) Completeness; 3) Safety; 4) An affordable price; 5) Frequency; 6) Accountability; 7) Regularity; 8) Comfort; 9) Capacity. In addition to the above factors. Consumer consideration in choosing transportation mode as follows: 1) Service aspect; 2) Reliability; 3) Reliability in motion; 4) Purposes; 5) Safety on the way; 6) Flexibility; 7) Fees; 8) Pollution Level; 9) Mileage; 10) Use of fuel; 11) Speed of movement [8]. To meet the needs of life that one of the main needs in human life is to eat, then the choice taken to meet the needs of life that are working as a provider of transportation services such as Bemo drivers.

\section{RESEARCH METHODS}

The age of respondents who filled the research questionnaire varied, in this study, the age group of respondents was divided into four groups: age 20-30 years, 31-40 years, 41-50 years,> 51 years. Based on the data, there were 17 people or $15 \%$ of respondents who filled questionnaires with age group of 20-30 years old, 53 people or $46 \%$ of respondents filled in questionnaires with age group 31-40 years old, and 33 persons (29\%) respectively 11 people $(10 \%)$ respondents who fill market with age group 41-50 years and $>51$ years old. The level of education of the respondents who filled the questionnaire was eliminated by the level of senior high school education/equivalent of 52 (seven) levels, namely SD, SMP, $\mathrm{S} 3, \%$ then $\mathrm{S} 1$ by $42 \%$, while for S3 does not exist and for elementary education, junior high school $1 \%$ and $2 \%$ respectively.

Status Ownership of Bemo transportation in this study, divided into two (2) categories i.e. yes and no. Based on the available data, the number of respondents with the ownership status of Bemo transportation service is $0 \%$, meaning that from 114 respondents none of them have transportation service of Bemo, in other words, that they are users or users of Bemo transportation services. Data collection techniques in this study are to spread Questionnaire about the public perception of transportation management Bemo impact on the income level of pedicab owner community.

The data to be collected is analyzed by descriptive statistics. Where the data obtained is changed in the form of numbers. Descriptive statistics are intended to illustrate the public perception of the management of Bemo transportation. Furthermore, to obtain a general description of the average level of public perception is done with the calculation of the average by the formula:

$$
\begin{gathered}
\mathrm{P}=\frac{\sum \mathrm{x}}{\mathrm{N}} \\
\mathrm{P}=\text { Average }, \mathrm{X}=\text { Value } / \text { price } \mathrm{x}, \mathrm{N}=\text { Amount of data }
\end{gathered}
$$

\section{RESULTS AND DISCUSSION}

\section{A. Planning}

Planning is a scheme of activities or ways formulated before doing activities so that goals can be achieved with the maximum. In this section will be explained the planning process of the motor vehicle company in providing transport services to the public. This planning process will begin by planning the bus capacity, determining the number of vehicles and revenues, scheduling, performance and service standards. As a company engaged in the field of transportation services, it is necessary to have a plan that includes the following:

1) Area and building operation. Namely planning a strategic place as a vehicle management center, including the secretariat office, the official parking location of the entire fleet, and place of repairs and other supporting equipment.

2) Capacity. That is, by knowing in advance the quantity of route or route that is usually the goal of society. By knowing the quantity of routes, it can be estimated how many buses will be operated and the itinerary.

3) Determination of vehicle number and travel time. Namely, determine the number of vehicles operated in one day. Because it requires large capital, the bus must try to minimize the quantity of bus needed to be more efficient. And setting the right travel time is the thing that can minimize the quantity of bus that will be operated to avoid the excess of the fleet.

4) Connection and socialization. Connections are people or institutions that are expected to participate in transportation service companies, and socialization is needed so that when the company operates, people already know the purpose and purpose of the establishment of the transportation service company.

5) Employee recruitment. After all the preparations have been completed, the next is to prepare employees who will work in the company, in the form: manager/director, administrative staff, and secretary, marketing staff, operations staff, security and general staff.

In this study, planning is limited to the following: Parking/bases, repairs/support equipment, route suitability, motor cycle quality, route settings, schedule arrangement, vehicle number, socialization, employee recruitment, fees. The public perception of the planning is done by the owner of the service of Bemo transit in Tempe District, $77 \%$ of respondents agreed respectively and $37 \%$ strongly agree, so that the owner of the transportation service of Bemo to pay attention to matters relating to the planning in providing pedicab transport services (see Figure 1). 


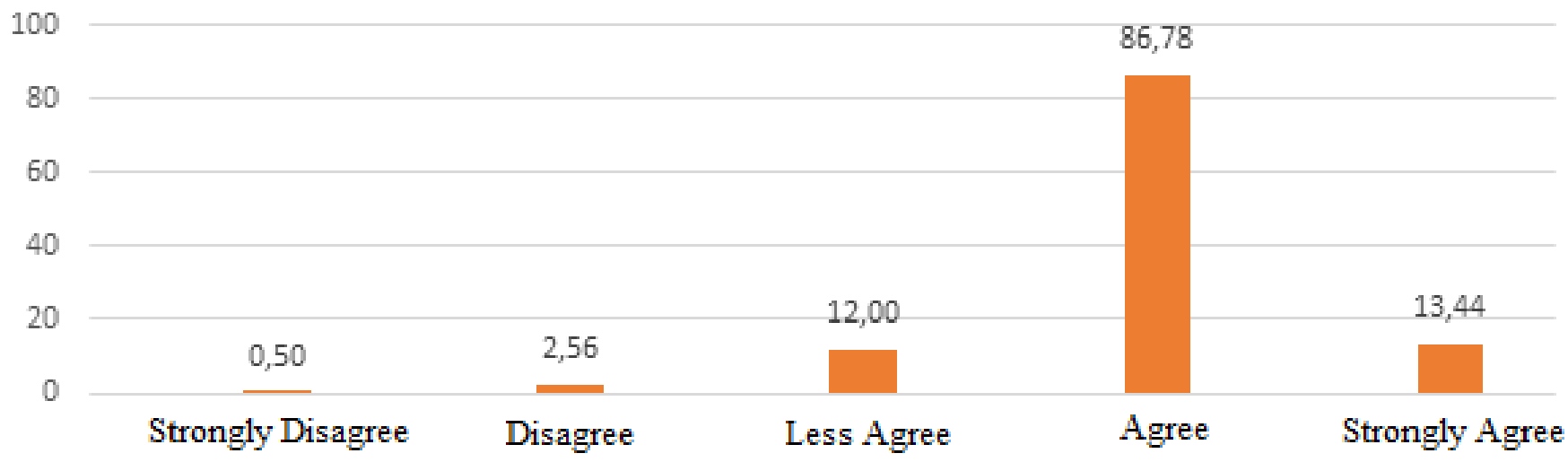

Fig. 1. Public perception of the planning of Bemo transportation services

\section{B. Organizing}

Actually organizing system has been done from the beginning, but the speakers here focuses particularly on organizing in the management of facilities and services to the exclusion of other things that are also spelled organizing system. Organizing a process of management in the form of supervision and assignment, this is due to the division of labor vertically and horizontally, but it all can not be separated from the procedures, processes and objectives to be achieved in the framework of cooperation, which begins with the creation of organizational structure, then proceed with the staffing procession. In this study, organizing includes: employee placement, distance and travel time, and fuel. Based on the existing data, $2.7 \%$ of respondents treated disagreed, 5\% of respondents answered less agree and $83.3 \%$ of respondents agreed and $23 \%$ of respondents answered strongly agree, this indicates that the provider of pedicab transportation services motor to keep paying attention and consider matters relating to organizing, the following can be visualized in the image below:

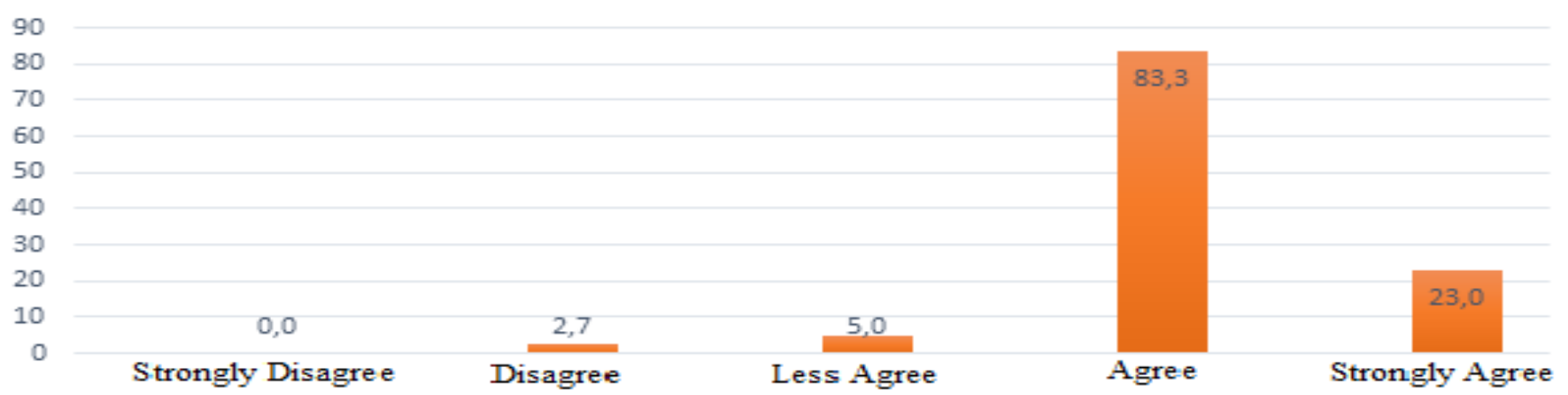

Fig. 2. Public perception on the organization of Bemo transportation services

\section{Control}

Supervision is the principal activity of management so that all work can be carried out in accordance with the plans and conditions outlined. Supervision must be done systematically and continuously in order to avoid deviations and other problems that will arise. And most important is the supervision not only with the strength alone, but must be in accordance with the function and the system so as not in vain. Supervision can be done in the charts, forms, notes, reports, visits, and whether they are in accordance with applicable rules and norms. And the results of the

supervision will be taken an assessment or evaluation. In this study, the supervisory stage includes: monitoring, reliability and safety level. Based on the results of data analysis shows that each of as much as $0.33 \%$; $2.33 \%$; $13.33 \%$ of respondents by responding strongly disagree, disagree and disagree, while as many as $86.33 \%$ of respondents agree and $11.67 \%$ strongly agree. In other words, the community is expecting this stage of control to be applied in the transportation service of Bemo. Here is the perception of the community in the stage of control can be seen in the picture below: 


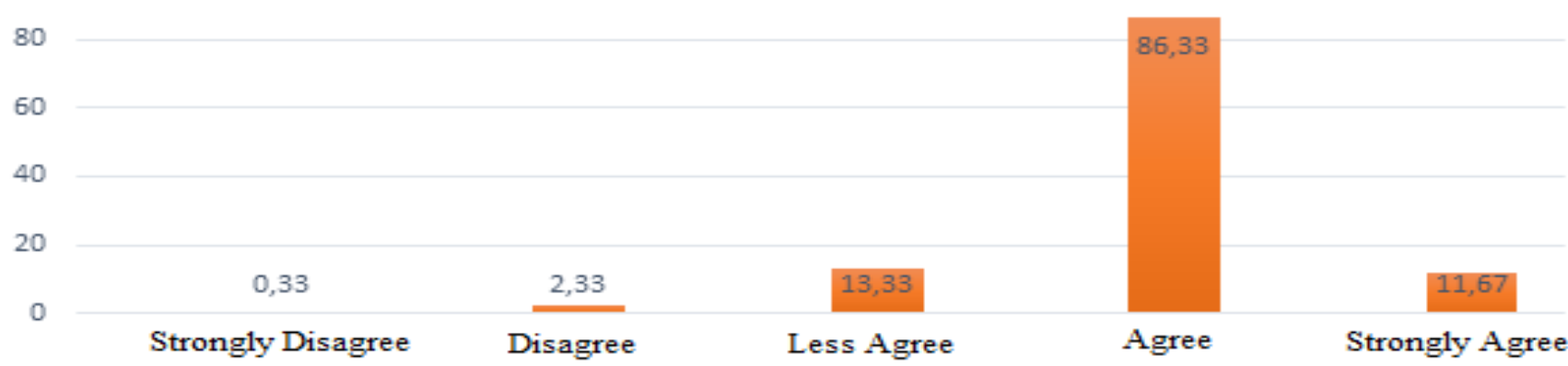

Fig. 3.. Public perception on the control of Bemo transportation services

\section{Monitoring and Evaluation}

The evaluation aims to find out where the predetermined objectives can be achieved, which activities beam completed data that is in the process of completion and what obstacles faced and formulate strategies to anticipate the errors that occur. Evaluation activities include:

1) Studying the progress of the business or activity continuously using monitoring.

2) Conduct measurement of success rate according to a certain program.
3) Making efforts to solve the constraints that arise to smooth the activities undertaken.

In this study, the evaluation stage includes measuring the success rate of the program with the aim to know the achievement of the planned program. The results of data analysis showed that as many as $77 \%$ of respondents agree and $37 \%$ of respondents strongly agree. This indicates that this evaluation stage is an important thing to be noticed by the owners of transportation services. The following can be seen in the picture below about the public perception of the evaluation phase:

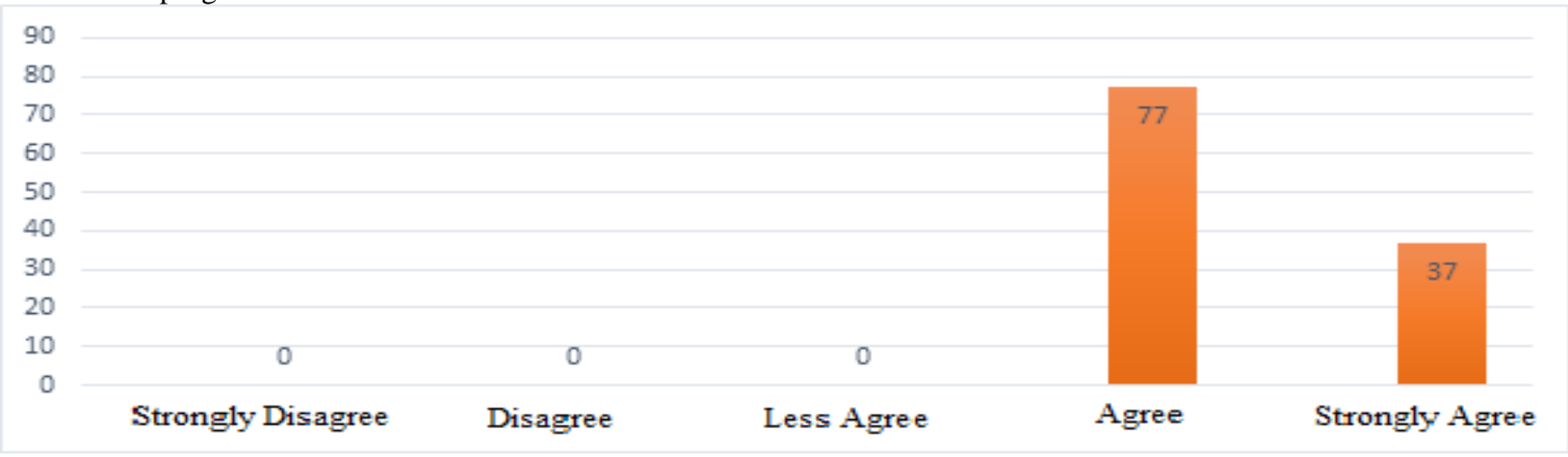

Fig. 4. Public perceptions of the evaluation of Bemo transportation services

\section{E. Discussion}

Transportation management system is a series of systems or management of modes of transportation by a group or class. Transportation services are one of the factors of income from production activities, trade, agriculture, and other economic activities. Humans desperately need transportation to meet the very diverse needs of life commonly associated with the production of goods and services. The convenience gained by transportation for humans is easy to overcome the distance between human resources with natural resources or the production goods that people need. Therefore, the importance of transportation for human life, it is necessary to do management or transportation management is good. In general, transportation management faces three main tasks:

1. Develop plans and programs to achieve the goals and mission of the organization as a whole.

2. Increase productivity and company performance.

3. Operate freight in outline.
Transportation management can be viewed from two sides: 1) Transport management in industry or company. 2) Management of transportation in the community (public transport). Bemo is one of the many public transports that is often used by the community in supporting their daily activities. Therefore, it is very important to improve services to the service users by improving the management of motorcycle transportation from planning, organizing, controlling and evaluation. It is also supported by various factors, namely: 1) Transportation is something that is needed by every human being as well as clothing and shelter, 2) Human and transportation needs are different, 3) The availability of transportation is very varied from small capacity, 4) slowly, cheaply, etc., 5) Transportation as an economic link, 6) Technology. Main Tasks of Transportation Management 1) Develop plans and programs to achieve the goals and mission of the organization as a whole, (2) Improve the productivity and performance of the company, 3) Operate transportation in outline. 


\section{CONCLUSION}

Based on the results of the research showed that the community generally agrees that Bemo transportation service in Tempe District Wajo Regency pays attention to transportation management covering: Planning, Organizing, Controlling, and Evaluation. It is suggested to the local government to issue an operational license for transportation services to be more selective and to consider the transportation management factor. To the community of users and owners of transportation services to pay attention to transportation management which includes planning, organizing, controlling and evaluation so that the user community feel safe and comfortable in utilizing the service of Bemor transportation.

\section{ACKNOWLEDGMENT}

Thanks to the Department of Transport, the head of the wajo Regency who contributed accurate data.

\section{REFERENCES}

[1] J. Wensveen, Air transportation: A management perspective. Routledge, 2018.

[2] J. Gehl, Life between buildings: using public space. Island Press, 2011.

[3] T. E. Notteboom* and J.-P. Rodrigue, "Port regionalization: towards a new phase in port development," Marit. Policy Manag., vol. 32, no. 3, pp. 297-313, 2005.

[4] P. Rietveld and F. Bruinsma, Is transport infrastructure effective?: transport infrastructure and accessibility: impacts on the space economy. Springer Science \& Business Media, 2012.

[5] V. R. Vuchic, Urban transit: operations, planning, and economics. John Wiley \& Sons, 2017.

[6] I. Dahlman et al., "Downregulation of electron transport chain genes in visceral adipose tissue in type 2 diabetes independent of obesity and possibly involving tumor necrosis factor- $\alpha$," Diabetes, vol. 55, no. 6, pp. 1792-1799, 2006.

[7] A. L. Kurniawan, "Analisis Faktor-faktor yang mempengaruhi pemilihan moda transportasi umum," 2014.

[8] P. Denholm and W. Short, "Evaluation of utility system impacts and benefits of optimally dispatched plug-in hybrid electric vehicles (Revised)," National Renewable Energy Laboratory (NREL), Golden, CO., 2006. 